\title{
Analisis Bentuk Pembinaan Narapidana Di Lembaga Pemasyarakatan Kelas IIA Kalianda
}

\author{
Candra Dian Tawawi ${ }^{1 *}$, Padmono Wibowo ${ }^{2}$ \\ ${ }^{1,2}$ Politeknik Ilmu Pemasyarakatan, Indonesia \\ Jalan Raya Gandul No. 4 Kec.Cinere, Kota Depok, Prov. Jawa Barat, Indonesia \\ *Correspondence email: bangcandradiantawawi2@gmail.com; padmonowibowo@gmail.com
}

\begin{abstract}
Abstrak. Pembinaan merupakan upaya negara untuk membuat narapidana sadar akan kesalahan, tidak akan mengulanginya, serta masyarakat dapat menerimanya, sehingga dia aktif di dalam pembangunan negara serta secara wajar berhidupan menjadi warga negara yang baik dan bertanggung jawab, sesuai dengan fungsinya bahwa tempat pembinaan adalah di Lembaga Pemasyarakatan agar mencapai tujuan Pemasyarakatan yaitu reintegrasi sosial. Metode penelitian yang digunakan didalam penelitian dengan melalui pendekatan penelitian kualitatif dimana data primer dan sekunder dianalisis berupa diuraikan berdasarkan gejala baik sifat serta mutu didalam peristiwa/kejadian didalam hukum realitas dan terhubung teori didalam data tambahan/sekunder, didapatkan hasil bentuk pembinaan di Lembaga Pemasyarakatan Kelas IIA Kalianda seperti kegiatan pembinaan berupa pembinaan kepribadian dan kemandirian, tahapan pembinaan narapidana terdiri dari tahap awal, tahap lanjutan dan tahap akhir, pelaksanaan pembinaan narapidana dilakukan dengan menetapkan pembinaan yang cocok bagi narapidana melalui sidang Tim Pengamat Pemasyarakatan yang diputuskan oleh Kepala Lembaga Pemasyarakatan dengan berkoordinasi dengan bagian pengamanan, hambatan pembinaan berasal dari dalam diri narapidana yang yang kurang berminat dalam mengikuti program pembinaan yang ada ataupun fasilitas untuk pembinaan yang kurang serta dapat diatasi melalui pendataan-pendekatan dan ajakan kepada narapidana serta kerjasama dengan pihak ke-3 dan hasil dari pembinaan berupa meningkatnya softskill serta dapat menjadi lebih bertakwa pada Tuhan
\end{abstract}

Kata Kunci: Pembinaan; Narapidana; Lembaga Pemasyarakatan

\begin{abstract}
Guidance is the state's effort for inmates to realize mistakes, not repeat, be accepted back, be active in the development, and live to be good and responsible citizens, under the function of guidance in prisons in the context of prisons, namely social reintegration. The research method used in the research is through a qualitative research approach where primary and secondary data are analyzed in the form of descriptions based on symptoms, and theory of association with additional/secondary data, the results are guidelines in the Class IIA Prison Kalianda Penitentiary obtained through personality development and independence activities. The stages of development for prisoners consist of initial, advanced, and final stages, the implementation of guidance by determining appropriate guidance for the correctional team session which is determined by the head of the correctional facility. Institutions coordinate with the security section, the constraints for coaching come from within prisoners who are less interested in participating in existing coaching programs or lack of coaching facilities and can be overcome through data collection, approaches, invitations to prisoners and collaboration with third parties as well as coaching results in the form of increased soft skills and can more devoted to God
\end{abstract}

Keyword: Development; Prisoners; Correctional Institutions

\section{PENDAHULUAN}

Kejahatan merupakan suatu hal yang biasa didalam kehidupan bermasyarakat, dimana masyarakat dapat memberikan kesempatan melakukannya dan menanggung semua akibat daripadanya walau tanpa sadar. Aspek kejahatan mengikuti perubahan zaman, semakin kompleks dan berkembangnya kejahatan maka semakin banyak masyarakat yang ingin mencari solusinya.

Aturan-aturan dibuat berdasarkan permintaan dari masyarakat tentang bagaimana cara mengatasi segala macam tindak kejahatan yang semakin berkembang serta sulit diatasi, langkah-langkah yang diambil dan terbukti efektif antara lain menggunakan sistem rehabilitasi, retribusi, penjeraan, serta pengasingan

Kitab Undang-Undang Hukum Pidana pada Pasal 10 tercantum jenis-jenis pidana, yaitu:

1. Pidana (pokok/utama), yaitu pidana mati/eksekusi mati, penjara di Lembaga Pemasyarakatan, pengurungan, didenda, serta tutupan.

2. Pidana (tambahan), yaitu dicabutnya hak khusus, dirampasnya barang tertentu, announcement hakim terkait putusan.

Unsur HAM di dalam pasal tersebut belum menjadi sebuah keutamaan sehingga yang terlihat hanya reaksi dari kejahatan yang dilakukan yang dilihat dari sudut pandang masyarakat, sedangkan resosialisasi seharusnya yang 
menjadi tujuan utama pemidanaan agar narapidana yang telah bebas berbaur di tengah masyarakat mempunyai ketahanan hidup sehingga tidak menajadi residivis kejahatan ${ }^{1}$.

Data harian pada tanggal 30 Agustus 2020 jumlah keseluruhan dari WBP(Warga Binaan Pemasyarakatan) di Lembaga Pemasyarakatan serta Rumah Tahanan Negara sebanyak 232.379 WBP di mana jumlah dari tahanan 49.215 tahanan sebanyak serta jumlah narapidana sebanyak 183.164 narapidana sedangkan batas jumlah hunian sebanyak 131,931 WBP sehingga over populasi sebanyak $74 \%^{2}$ dan keseluruhan WBP dibina di Lembaga Pemasyarakatan sesuai dengan ketentuan peraturan perundang-undangan yang harus didukung oleh masyarakat guna menyukseskan pembinaan agar tujuan Pemasyarakatan tercapai yaitu narapidana sadar akan kesalahan, tidak akan mengulanginya, serta masyarakat dapat menerimanya, sehingga dia akan aktif di dalam pembangunan negara serta secara wajar berhidupan menjadi warga negara yang baik dan bertanggung jawab

Nilai-nilai HAM serta kemanusiaan dijunjung tinggi oleh negara Indonesia yang diimplementasikan ke dalam lembaga pemasyarakatan berupa hak-hak yang dimiliki oleh narapidana yang wajib dipenuhi sesuai dengan pidato Dr. Sahardjo mengenai ide tentang Pemasyarakatan pada 5 Juli 1963 mengatakan bahwa Negara tidak sedikitpun mempunyai hak membuat seseorang lebih jahat/buruk disbanding dia sebelum memasuki lembaga pemasyarakatan ${ }^{3}$. Karena mereka hanya tersesat tidak ada kata telat didalam tobat dan tobat itu dibimbing bukan disiksa.

Di Lembaga Pemasyarakatan atau kemudian disingkat dengan LAPAS dimana hak serta kewajiban narapidana haruslah dipenuhi sesuai dengan UU No.12/1995 tentang Pemasyarakatan, tetapi dalam kondisi tertentu yang dirasakan narapidana di dalam Lembaga Pemasyarakatan seperti kurang tertarinkya narapidana pada kegiatan pembinaan dalam Lembaga Pemasyarakatan merupakan sebuah fenomena dari diri narapidana yaitu perilaku dan kepribadian narapidana saat sebelum berada didalam Lembaga Pemasyarakatan.

Narapidana merupakan seseorang terpidana yang berkekuatan hukum tetap yang didapat melalui proses peradilan dan menjalankan hukuman kehilangan kebebasan di Lembaga Pemasyarakatan, serta memiliki hak-hak yang dijunjung tinggi seperti berhak atas remisi, $\mathrm{PB}, \mathrm{CB}, \mathrm{CMB}, \mathrm{CMK}$ dll yang juga kewajiban yaitu menjunjung tinggi peraturan yang ada dan mengikuti pembinaan di Lapas dengan baik.

Sesuai Pasal 6 pada UU Pemasyarakatan, menyebutkan bahwa Pembinaan WBP oleh Lembaga Pemasyarakatan serta Pembimbingan WBP oleh BAPAS (Balai Pemasyarakatan). Pembinaan tersebut khusus kepada Narapidana dewasa dan anak-anak yang dibagi menjadi 2 (dua) jenis pembinaan, yaitu pembinaan kepribadian seperti program kerohanian sesuai agama yang dianut WBP dan pembinaan kemandirian seperti program untuk melatih skill guna bekal kembali ke masyarakat.

Sesuai amanat Soekarno yang merubah istilah penjara menjadi istilah baru yaitu pemasyarakatan yang bertepat pada konferensi dinas dan pembuatan piagam pemasyarakatan yang tepat berada di hari Senin, 27 April 1964 ${ }^{4}$.

Menurut banyak pendapat bahwa terjadi kerancuan pada definisi apa itu pemasyarakatan sebagian berpendapat bahwa pemasyarakatan itu memberikan kelonggaran-kelonggaran pada narapidana, sebagian mewujudkan pemasyarakatan sebagai perlakuan terakhir (fase behandeling) ataupun berpendapat sebagai upaya resosialisasi.

Namun Sudarto berpendapat bahwa istilah resosialisasi tidak ada bedanya dengan pemasyarakatan namun istilah tersebut hanyalah sebuah istilah biasa akan tetapi kaidah didalamnya yaitu bagaimana pemasyarakatan didalam pelaksanaanpembinaan,cara pembinaan, serta hasil yang didapatkan dari pembinaan tersebut ${ }^{5}$.

Roeslan Saleh memberikan gambaran yaitu: sesuatu yang diusahakan agar tercapainya tujuan narapidana kelak dapat bertahan hdup berbaur dengan masyarakat tanpa berbuat ulah kembali ${ }^{6}$. dengan kata lain bahwa pemasyarakatan tidak lepas dengan istilah pembinaan beserta cara-cara dalam melakukan pembinaan itu sendiri.

Hal ini disinggung tepatnya didalam tahapan pembinaan yang dapat dilakukan bimbingan-bimbingan kepada narapidana seperti yang disampaikan oleh Bambang Purnomo mengatakan bahwa pembinaan bersama pembimbingan dapat dibuat program antara lain bimbingan:

1. Aspek mental, baik melalui kegiatan keagamaan agar menumbuhkan rasa bersalah serta tidak mau mengulangi kejahatan

2. Aspek sosial, memberikan arahan agar dapat hidup berbaur dengan masyarakat kelak

3. Aspek keterampilan, dibuatkan kegiatan sesuai dengan bakat dan minat keterampilan

4. Pembimbingan untuk tetap menjaga kemanan

${ }^{1}$ Roeslan Saleh, Perbuatan Pidana Dan Pertanggung Jawaban Pidana (Jakarta: Centara, 1983).

${ }^{2}$ Ditjen PAS, "Data Terakhir Jumlah Penghuni Perkanwil," - SMS Gateway System, last modified 2020, http://smslap.ditjenpas.go.id/public/grl/current/daily.

${ }^{3}$ Simon.R. A.Joasis - Suryano Thomas, Study Kebudayaan Lembaga Pemasyarakatan Di Indonesia (Bandung: Lubuk Agung, 2011).

${ }^{4}$ S.H Dr.Bambang Purnomo, Kapita Selekta Hukum Pidana (Yogyakarta: Liberty, 1988).

${ }^{5}$ B Suryobroto, Pelaksanaan Sistem Pemasyarakatan (Jakarta: Departemen Kehakiman R, 1972).

${ }^{6}$ Ibid 
5. Pembimbingan lainnya seperti penyuluhan kesehatan ataupun yang berhubungan dengan masyarakat kelak. ${ }^{7}$

Sedangkan pembinaan di Lembaga Pemasyarakatan merupakan upaya negara untuk membuat narapidana sadar akan kesalahan, tidak akan mengulanginya, serta masyarakat dapat menerimanya, sehingga dia akan aktif di dalam pembangunan negara serta secara wajar berhidupan menjadi warga negara yang baik dan bertanggung jawab, sesuai dengan fungsinya bahwa tempat pembinaan adalah di Lembaga Pemasyarakatan.

Dalam pembinaan ada peranan sesuatu yang membuat orang didalamnya mencapai kemampuan tertentu sehingga mencapai tujuan organisasinya, jika dikaitkan dengan tugas dan dasar hukum di Pemasyarakatan yaitu pembinaan agar narapidana sadar akan kesalahan, tidak akan mengulanginya, serta masyarakat dapat menerimanya, sehingga dia akan aktif di dalam pembangunan negara serta secara wajar berhidupan menjadi warga negara yang baik dan bertanggung jawab, dengan itu maka tujuan organisasi untuk resosialisasi/reintegrasi sosial tercapai.

Dalam PP Nomor 31/1999 tentang Pembinaan dan Pembimbingan WBP dan PP Nomor 32/1999 tentang Syarat dan Tata Cara Pemberian Hak WBP merupakan suatu keharusan dimana merupakan implementasi dari UU Nomor 12/1995 tentang Pemasyarakatan Pasal 7(2), dan dalam PP 32/1999 merupakan implentasi juga dari UU Nomor 12/1995 tentang Pemasyarakatan Pasal 14(2), Pasal 22(2), 29(2), dan 32(2).

Pembinaan ini bertujuan agar narapidana sadar akan kesalahan, tidak akan mengulanginya, serta masyarakat dapat menerimanya, sehingga dia akan aktif di dalam pembangunan negara serta secara wajar berhidupan menjadi warga negara yang baik dan bertanggung jawab, dimana pembinaan sendiri tidak hanya melibatkan petugas sebagai Pembina tetapi juga masyarakat sebagai tempat kelak ia kembali dan yang dibina sebagai subyek pembinaannya, maka dianggap perlu melakukan pendekatan-pendekatan terhadap narapidana.

Pembinaan narapidana sendiri haruslah ada pembeda baik di LAPAS serta yang ada di LAPAS terbuka baik secara pembinaan maupun secara memberikan kebijakan haruslah berbeda walaupun menurut ketentuan tugas dan fungsinya adalah sama yaitu pembinaan narapidana, namun menurut hakikat fungsinya jelaslah berbeda dari segi tingkat keamananannya ${ }^{8}$.

Sehingga penelitian ini ditujukan untuk mengetahui bentuk pembinaan baik kegiatan pembinaan, tahapan pembinaan dan pelaksanaan pembinaan narapidana di lembaga pemasyarakatan serta kendala yang dihadapi dalam melaksanakan pembinaan narapidana dan upaya dalam mengatasinya serta bekal bagi narapidana yang didapat selama melakukan pembinaan dilembaga pemasyarakatan, agar dapat dijadikan bahan pertimbangan kebijakan pemerintah.

\section{METODE}

Metode penelitian yang digunakan didalam penelitian dengan melalui pendekatan penelitian kualitatif dimana data primer dan sekunder dianalisis berupa diuraikan berdasarkan gejala baik sifat serta mutu didalam peristiwa/kejadian didalam hukum realitas dan merupakan indikasi data utama/primer yang terhubung teori didalam data tambahan/sekunder. Data-data tersebut kemudian diruntutkan serta dijelaskan berdasarkan hasil yang ada dan dituang kedalam artikel ini, dimana penulis tetap memprioritaskan kaidah aturan hukum yang telah eksis dengan tetap melihat factor non-yuridis. ${ }^{9}$

Data primer didapatkan melalui wawancara bersama informan yang dirasa mampu memberikan informasi akurat mengenai pembinaan di lembaga pemasyarakatan, yaitu 2 orang staf Sub Seksi Bimbingan Kemasyarakatan dan Perawatan (Subsi Bimkemaswatwat) serta data sekunder merupakan data pendukung yang berasdal dari studi pustaka berupa buku, skripsi, artikel peraturan perundang-undangan serta halaman website.

\section{HASIL DAN PEMBAHASAN \\ Kegiatan Pembinaan Di Lapas}

Berdasarkan hasil wawancara yang dilakukan kepada staf Subsi Bimkemaswat didapatkan bahwa pembinaan yang ada dalam Lapas Kelas IIA Kalianda berupa pembinaan terbagi kedalam kepribadian dan kemandirian contohnya antara lain pembinaan terhadap ketakwaan kepada Tuhan Yang Maha Esa di setiap agama dibina sesuai dengan kepercayaan masing-masing narapidana serta pembinaan kesadaran berbangsa dan bernegara dimana narapidana diajak ikut serta dalam upacara-upacara di Lapas serta pembinaan jasmani dan rohani, seperti olahraga, pelayanan kesehatan serta ada pembinaan kesadaran hukum dengan melakukan penyuluhan-penyuluhan serta mengundang instansi luar untuk melakukan pembinaan, ada juga program berupa reintegrasi dengan $\mathrm{PB}, \mathrm{CB}$ serta terdapat

7 M.H. Dr.Ruslan Renggong, S.H., Memahami Perlindungan HAM Dalam Proses Penahanan Di Indonesia (Jakarta: Prenamedia Group Jakarta, 2014).

8 Ahmad Sanusi, "Evaluasi Pelaksanaan Pembinaan Narapidana Di Lembaga Pemasyarakatan Terbuka,” Jurnal Ilmiah Kebijakan Hukum 13, no. 2 (2019): 123.

9 Widya Islamiyah et al., "Analisis Yuridis Terhadap Pembinaan Narapidana Di Lembaga Pemasyarakatan Klas IIB Barru," 2017. 
keterampilan kerja dan produksi berupa pelatihan pertukangan, pengelasan, bercocok tanam dan perikanan, hal ini sesuai dengan yang telah dijelaskan UU Pemasyarakatan pada Pasal 7(1) dan 7(2) bahwa penyelenggaraan pembinaan serta pembimbingan dilakukan pelaksanaannya oleh petugas selanjutnya akan diatur oleh PP, pada penjelasan UU Pemasyarakatan pada Pasal 7(2) dimana pembinaan terbagi kedalam kepribadian yang mengarah ke perubahan sikap dan perilaku serta kemandirian yang mengarah ke keterampilan dan bakat

\section{Tahapan Pembinaan Narapidana}

Berdasarkan hasil wawancara dengan staf Subsi Bimkemaswat didapatkan bahwa tahapan pembinaan yang ada di Lapas kelas IIA Kalianda dimulai dari tahap awal yaitu dari mulainya masuk narapidana menjalani masa mapenaling sampai dengan 1/3 (satu pertiga) masa pidana (MP) kemudian dilanjutkan dengan tahap lanjutan mulai dari $1 / 3$ (satu pertiga) MP sampai dengan $1 / 2$ (setengah) MP kemudian diakhiri dengan tahap akhir mulai dari $1 / 2$ (setengah) MP sampai dengan 2/3 (dua pertiga) MP, di dalamnya terdapat program integrasi yaitu PB/Pembebasan Bersayarat, $\mathrm{CB} / \mathrm{Cuti}$ Bersyarat, $\mathrm{CMB} / \mathrm{Cuti}$ Menjelang Bebas, serta CMK/Cuti Mengunjungi Keluarga, walaupun tidak diatur dalam UU Pemasyarakatan akan tetapi sesuai dengan Pasal 7 ayat 2 bahwa pengaturan lebih lanjut tentang pembinaan dan pembimbingan diatur oleh Peraturan Pemerintah maka dikeluarkanlah PP 31/1999 tentang Pembinaan dan Pembimbingan WBP di Pasal 7 dijelaskan 3 tahapan pembinaan, yaitu tahap awal, tahap lanjutan dan tahap akhir di mana setiap pengakhiran tahapan dilaksanakan sidang Tim Pengamat Pemasyarakatan, kemudian dijelaskan Pasal 9 dijelaskan pembinaan tahap awal dari masuk sampai dengan sepertiga masa pidana sedangkan tahap lanjutan dibagi 2 lanjutan pertama dan lanjutan kedua, pada lanjutan pertama dari awal masuk sampai dengan setengah masa pidana lanjutan kedua yaitu dari 1/2 masa pidana sampai dengan $2 / 3$ sedangkan ditahap akhir dilaksanakan dari terakhir dari tahap lanjutan sampai dengan terakhir dari masa pidana, pada Pasal 10 diperjelas bahwa tahap awal dilaksanakan 1 bulan mapenaling dengan dilakukan pencanangan pelaksanaan dan penilaian tahap awal pada pembinaan kepribadian serta pembinaan kemandirian kemudian dilanjutkan dengan tahap lanjutan di mana dilaksanakan perencanaan, pelaksanaan dan penilaian ditambah program asimilasi sedangkan di tahap akhir dilaksanakan perencanaan pelaksanaan integrasi serta pengakhiran pelaksanaan pembinaan tahap akhir dan diakhiri, pada Pasal 11 bahwa pembinaan di Lapas adalah di tahap awal dan tahap lanjutan sedangkan Bapas melaksanakntahap akhir. Dalam tahapan pembinaan dapat dilakukan bimbingan-bimbingan kepada narapidana seperti yang disampaikan oleh Bambang Purnomo mengatakan bahwa pembinaan bersama pembimbingan dapat dibuat program antara lain bimbingan:

1. Aspek mental, baik melalui kegiatan keagamaan agar menumbuhkan rasa bersalah serta tidak mau mengulangi kejahatan

2. Aspek sosial, memberikan arahan agar dapat hidup berbaur dengan masyarakat kelak

3. Aspek keterampilan, dibuatkan kegiatan sesuai dengan bakat dan minat keterampilan

4. Pembimbingan untuk tetap menjaga kemanan

5. Pembimbingan lainnya seperti penyuluhan kesehatan ataupun yang berhubungan dengan masyarakat kelak. ${ }^{10}$

\section{Pelaksanaan Pembinaan Narapidana}

Berdasarkan hasil wawancara dengan Subsi Bimkemaswat didapatkan bahwa pelaksanaan pembinaan dilakukan menetapkan pembinaan yang cocok bagi narapidana melalui sidang tim pengamat Pemasyarakatan atau sidang TPP yang diputuskan oleh kepala lembaga pemasyarakatan dengan berkoordinasi dengan bagian pengamanan. Sesuai dengan Pasal 45(4) UU Pemasyarakatan bahwa Tim Pengamat Pemasyarakatan(TPP) berisi pimpinan/pejabat yang ada di Lapas/Bapas untuk pemberian saran kegiatan pembinaan dan pembimbingan serta membuat penilaiannya dan menerima keluhan serta pengaduan WBP, dijelaskan pula pada Pasal 7(3) PP 31/1999 tentang Pembinaan dan Pembimbingan WBP bahwa pengalihan tahapan melalui sidang TPP, kemudian pada Pasal 10(4) dijelaskan bahwa pentahapan melalui sidang TPP, pada Pasal 5 dilanjutkan bahwa dalam sidang Kalapas harus memperhatikan hasil Penelitian Kemasyarakatan/LITMAS, pada Pasal 17(3) bahwa pengalihan tahapan pembinaan dilaksanakan melalui sidang TPP di dasarkan data pembinaan, pembimbing kemasyarakatan/PK, pengamanan, serta wali anak pidana, pada Pasal 19(4) bahwa pentahapan pembinaan melalui sidang TPP dimana pada Pasal 5 diatas dijelaskan bahwa dalam sidang Kalapas tetap wajib memperhatikan Penelitian Kemasyarakatan/LITMAS, pada Pasal 33(2) bahwa pembimbingan tahapannya dilakukan dengan melalui sidang TPP, pada Pasal 39(4) bahwa pentahapan pembimbingan Klien Pemasyarakatan ditetapkan melalui sidang TPP Bapas.

\section{Hambatan Didalam Pembinaan Narapidana}

Berdasarkan hasil wawancara dengan staf Subsi Bimkemaswat didapatkan bahwa hambatan yang dihadapi oleh Lapas kelas IIA Kalianda mengenai hal pembinaan di antaranya merupakan berasal dari dalam diri narapidana yang 
yang kurang berminat dalam kegiatan pembinaan di Lapas kelas IIA Kalianda. Dalam hal ini UU tidak membahas hambatan didalam pembinaan namun hambatan pasti akan muncul dalam proses pembinaan narapidana. Baik secara internal maupun eksternal, secara internal seperti dari diri individu narapidana sendiri yang tidak mau mengikuti pembinaan ataupun secara ekternal seperti fasilitas untuk pembinaan narapidana yang kurang dari pemerintah. Kendala dilembaga pemasyarakatan merupakan hal klasik apalagi yang berhubungan dengan pembinaan narapidana. Didalam melaksanakan pembinaan adalah hal sedikit sulit dilaksanakan seperti contohnya dalam pembinaan kepribadian yang dimana berfokus pada perubahan sikap serta kepribadian dari diri narapidana dengan melalui kegiatan-kegiatan berupa kegiatan keagamaan yang sesuai dengan keyakinan atau agama kepercayaan setiap narapidana dilembaga pemasyarakatan, namun di dalam pembinaan masih banyak terdapat kekurangan serta kekurangan efektifan baik sarana serta prasarana serta dukungan dari pihak pihak ketiga serta masih banyak kendala mengenai over kapasitas di lembaga pemasyarakatan hal ini perlu dilakukan kerjasama kerjasama agar kegiatan pembinaan dapat berjalan dengan baik ${ }^{11}$.

Kendala-kendala di atas tidak hanya dibatasi atas masalah tersebut bisa jadi pembinaan di lembaga pemasyarakatan lain seperti kendala baik itu tenaga profesional maupun kualitas pembinaan yang kurang maksimal dapat berperan pula di dalam menghambat proses pembinaan narapidana, sehingga pembinaan yang seharusnya dapat menentukan berhasil tidaknya tujuan pemasyarakatan setelah masa pidana narapidana itu berakhir dan kembali kemasyarakat ${ }^{12}$.

Dapat pula kita lihat dari kacamata lebih luas lagi apabila narapidana telah bebas kelak berbaur kembali kedalam masyarakat, stigma atau cap jelek mengenai mantan narapidana yang melekat seumur hidup dapat membuat hambatan tersendiri didalam pembinaan yang akan menimbulkan masalah baru yaitu residivis atau pengulangan tindak kejahatan sehingga pembinaan menjadi sia-sia ${ }^{13}$.

\section{Upaya Lapas Dalam Menanggulangi Hambatan Dalam Pembinaan}

Berdasarkan hasil wawancara dengan staf Subsi Bimkemaswat didapatkan bahwa upaya yang dilakukan Lapas kelas IIA Kalianda dengan melakukan pendataan kepada narapidana yang akan mengikuti program pembinaan serta dilakukan pendekatan pendekatan untuk mengetahui problem atau masalah apa yang didapati oleh narapidana sehingga tidak mengikuti pembinaan kemudian dengan diadakan ajakan-ajakan kepada narapidana agar mengikuti program pembinaan dengan baik. Dalam mengatasi hambatan pembinaan yang dilakukan Lapas kelas IIA Kalianda telah baik, namun sesuai Pasal 9(1) dan 9(2) UU Pemasyarakatan yaitu menteri dapat bekerjasama baik bersama instansi/badan kemasyarakatan lain/perorangan dalam hal pembinaan dan akan selanjutnya diatur oleh PP kemudian oleh penjelasan pada ayat 2 bahwa kerjasama dapat dilakukan pada bidang pembinaan seperti agama, keterampilan, bermasyarakat, hukum, pendidikann serta reintegrasi sosial.

\section{Bekal Hasil Dari Pembinaan Narapidana}

Berdasarkan hasil wawancara dengan staf Subsi Bimkemaswat didapatkan bahwa bekal atau hasil dari pembinaan yang didapatkan di Lapas kelas IIA Kalianda sangat banyak, apabila mengikuti program pembinaan dengan baik dan tekun dapat meningkatkan keterampilan yang tidak mereka dapat sebelumnya diluar lapas serta dapat menjadi lebih bertakwa pada Tuhan melalui program pembinaan keagamaan serta dengan bekal tersebut diharapkan ketika keluar dapat diterima masyarakat keluarga serta punya keterampilan tambahan. Pada Pasal 1(2) UU Pemasyarakatan bahwa sistem Pemasyarakatan merupakan peraturan dengan arah, batas dan cara pembinaan WBP didasarkan pada Pancasila dengan bersinergi anatara narapidana, petugas serta masyarakat agar narapidana sadar akan kesalahan, tidak akan mengulanginya, serta masyarakat dapat menerimanya, sehingga dia akan aktif di dalam pembangunan negara serta secara wajar berhidupan menjadi warga negara yang baik dan bertanggung jawab dan sesuai penjelasan pada Pasal 5(a) UU Pemasyarakatan bahwa pengayoman merupakan suatu perlakuan pada WBP untuk melindungi masyarakat dari kemungkinan pengulangan kejahatan oleh WBP serta memberi perbekalan pada WBP agar menjadi bermanfaat didalam masyarakat. Sehingga sesuai dengan pendapat Roeslan Saleh yang memberikan gambaran yaitu: sesuatu yang diusahakan agar tercapainya tujuan narapidana kelak dapat bertahan hdup berbaur dengan masyarakat tanpa berbuat ulah kembali ${ }^{14}$.

11 Nurhamidah Gajah, "Pembinaan Narapidana Anak Di Lembaga Pemasyarakatan Kelas IIB Padangsidimpuan," AlMuaddib : Jurnal Ilmu-Ilmu Sosial \& Keislaman 2, no. 1 (2017): 163-183.

${ }^{12}$ Cindi Kleri Romania Sausele, "Pelaksanaan Pembinaan Narapidana Lanjut Usia ( Lansia) Di Lembaga Pemasyarakatan ( Studi Di Lembaga Pemasyarakatan Kelas Ii a Mataram )," Fakultas Hukum Universitas Mataram 1, no. 9 (2018): 1-16.

13 Ayu Octis Pratiwi, "Pembinaan Narapidana Remaja Di Lembaga Pemasyarakatan (Studi Lembaga Pemasyarakatan Kelas II A Kota Metro),” Pembinaan, 2016, http://digilib.unila.ac.id/.

14 Ibid 


\section{SIMPULAN}

Kegiatan pembinaan di lapas yaitu berupa pembinaan yang terbagi kedalam kepribadian dan kemandirian sesuai dengan yang telah dijelaskan pada Pasal 7(1) dan 7(2) UU Pemasyarakatan. Tahapan pembinaan narapidana dari tahap awal, dilanjutkan dengan tahap lanjutan kemudian diakhiri dengan tahap akhir sesuai pada Pasal 7, 9, 10, dan 11 PP 31/1999 tentang Pembinaan dan Pembimbingan WBP.

Pelaksanaan pembinaan narapidana dilakukan menetapkan pembinaan yang cocok bagi narapidana melalui sidang TPP yang diputuskan oleh kepala dengan berkoordinasi dengan bagian pengamanan. Sesuai Pasal 45(4) UU Pemasyarakatan, serta pada Pasal 5, 7(3), 10(4), 17(3), 19(4), 33(2), dan 39(4) PP 31/1999 tentang Pembinaan dan Pembimbingan WBP

Hambatan didalam pembinaan narapidana berasal dari dalam diri narapidana yang yang kurang berminat dalam mengikuti program pembinaan yang ada ataupun fasilitas untuk pembinaan narapidana yang kurang dari pemerintah. Upaya lapas dalam menanggulangi hambatan dalam pembinaan dengan melakukan pendataan, pendekatan kemudian dengan diadakan ajakan-ajakan kepada narapidana serta kerjasama pihak ke-3 sesuai dengan Pasal 9(1) dan 9(2) UU Pemasyarakatan

Bekal hasil dari pembinaan narapidana adalah meningkatnya keterampilan yang tidak mereka dapat sebelumnya diluar lapas serta dapat menjadi lebih bertakwa pada Tuhan melalui program pembinaan keagamaan serta dengan bekal tersebut diharapkan ketika keluar dapat diterima masyarakat keluarga serta punya keterampilan tambahan. Sesuai dengan Pasal 1(2) dan Pasal 5(a) UU Pemasyarakatan

\section{DAFTAR PUSTAKA}

\section{Buku}

Cindi Kleri Romania Sausele. "Pelaksanaan Pembinaan Narapidana Lanjut Usia ( Lansia) Di Lembaga Pemasyarakatan ( Studi Di Lembaga Pemasyarakatan Kelas Ii a Mataram )." Fakultas Hukum Universitas Mataram 1, no. 9 (2018): 1-16.

Ditjen PAS. "Data Terakhir Jumlah Penghuni Perkanwil." - SMS Gateway System. Last modified 2020. http://smslap.ditjenpas.go.id/public/grl/current/daily.

Dr.Bambang Purnomo, S.H. Kapita Selekta Hukum Pidana. Yogyakarta: Liberty, 1988.

Dr.Ruslan Renggong, S.H., M.H. Memahami Perlindungan HAM Dalam Proses Penahanan Di Indonesia. Jakarta: Prenamedia Group Jakarta, 2014.

Gajah, Nurhamidah. "Pembinaan Narapidana Anak Di Lembaga Pemasyarakatan Kelas IIB Padangsidimpuan." AlMuaddib : Jurnal Ilmu-Ilmu Sosial \& Keislaman 2, no. 1 (2017): 163-183.

Islamiyah, Widya, Departemen Hukum Pidana, Fakultas Hukum, and Universitas Hasanuddin. "Analisis Yuridis Terhadap Pembinaan Narapidana Di Lembaga Pemasyarakatan Klas IIB Barru," 2017.

Pratiwi, Ayu Octis. "Pembinaan Narapidana Remaja Di Lembaga Pemasyarakatan (Studi Lembaga Pemasyarakatan Kelas II A Kota Metro).” Pembinaan, 2016. http://digilib.unila.ac.id/.

Saleh, Roeslan. Perbuatan Pidana Dan Pertanggung Jawaban Pidana. Jakarta: Centara, 1983.

Sanusi, Ahmad. "Evaluasi Pelaksanaan Pembinaan Narapidana Di Lembaga Pemasyarakatan Terbuka." Jurnal Ilmiah Kebijakan Hukum 13, no. 2 (2019): 123.

Suryobroto, B. Pelaksanaan Sistem Pemasyarakatan. Jakarta: Departemen Kehakiman R, 1972.

Thomas, Simon.R. A.Joasis - Suryano. Study Kebudayaan Lembaga Pemasyarakatan Di Indonesia. Bandung: Lubuk Agung, 2011.

\section{Skripsi}

Islamiyah, Widya, Departemen Hukum Pidana, Fakultas Hukum, and Universitas Hasanuddin. "Analisis Yuridis Terhadap Pembinaan Narapidana Di Lembaga Pemasyarakatan Klas IIB Barru,” 2017.

Pratiwi, Ayu Octis. "Pembinaan Narapidana Remaja Di Lembaga Pemasyarakatan (Studi Lembaga Pemasyarakatan Kelas II A Kota Metro)." Pembinaan, 2016. http://digilib.unila.ac.id/.

\section{Peraturan perundang-undangan}

Peraturan Pemerintah Nomor 31 Tahun 1999 Tentang Pembinaan Dan Pembimbingan Warga Binaan Pemasyarakatan Peraturan Pemerintah Nomor 32Tahun 1999 Tentang Syarat Dan Tata Cara Pelaksanaan Hak Warga Binaan Pemasyarakatan

Undang-Undang Nomor 12 Tahun 1995 tentang Pemasyarakatan

\section{Jurnal}

Cindi Kleri Romania Sausele. "Pelaksanaan Pembinaan Narapidana Lanjut Usia ( Lansia) Di Lembaga Pemasyarakatan ( Studi Di Lembaga Pemasyarakatan Kelas Ii a Mataram )." Fakultas Hukum Universitas 
Mataram 1, no. 9 (2018): 1-16.

Gajah, Nurhamidah. "Pembinaan Narapidana Anak Di Lembaga Pemasyarakatan Kelas IIB Padangsidimpuan." AlMuaddib : Jurnal Ilmu-Ilmu Sosial \& Keislaman 2, no. 1 (2017): 163-183.

Sanusi, Ahmad. "Evaluasi Pelaksanaan Pembinaan Narapidana Di Lembaga Pemasyarakatan Terbuka." Jurnal Ilmiah Kebijakan Hukum 13, no. 2 (2019): 123.

\section{Internet}

Ditjen PAS. "Data Terakhir Jumlah Penghuni Perkanwil." - SMS Gateway System. Last modified 2020. http://smslap.ditjenpas.go.id/public/grl/current/daily. 